\title{
Microbial life in deep granitic rock
}

In recent years, there has been rapid increease in the numbers of the published papers on aspects of the microbiology of subterranean environments. There has been a significant expansion in the understanding on microbial ecology in shallow ground water systems down to some $50-100 \mathrm{~m}$, accurately reviewed by Ghiorse and Wilson (1988) and Matthess et al. (1992), and our knowledge is currently increasing about deeper crustal environments (Fredrickson and Onstott; 1996, Pedersen, 1993a, 1996; Stevens and McKinley, 1995). Deep subterranean environments vary considerably in composition, from soft sandstone and hardened sedimentary rocks to very hard igneous rock types. Here, microbial life in one of the hardest and most common rock types of the earth's crust, granite, is discussed.

\section{Biogeochemical processes}

A full understanding of deep subterranean environments cannot be achieved until microbial processes are included in models, theories and interpretation of results. This is because microbes catalyse many reactions that, for kinetic reasons, are very slow or not possible at low temperature and pressure. One obvious example is the bacterial reduction of sulphate to sulphide in anoxic waters. Another example is that bacterial activity usually influences the redox potential in the environment. If, for instance, the environment is rich in $\mathrm{Fe}^{3+}$ and organic matter, iron-reducing bacteria will dominate, produce $\mathrm{Fe}^{2+}$ and carbon dioxide in large quantities and the resulting redox will be controlled by $\mathrm{Fe}^{2+}$ at or below approximately $-100 \mathrm{mV}$. A third example is methane producing microorganisms that typically coexist syntrophically with hydrogen producing bacteria that ferment and respire organic material. If the hydrogen concentration increases too much, the decomposition of organic material by these bacteria stops. As methanogens produce methane from hydrogen and carbon dioxide, they remove hydrogen from the environment and the bacterial decomposition of organic material can continue.

Microbial decomposition and production of organic material depend on the sources of energy and electron-acceptors present. Organic carbon, reduced inorganic molecules or hydrogen are possible energy sources in subterranean environments. During microbial oxidation of these energy sources the microbes use electron acceptors in a certain order according to Figure 1. First oxygen is used, thereafter follows the utilisation of nitrate, manganese, iron, sulphate, sulphur and carbon dioxide .

Simultaneously, fermentative processes supply the respiring microbes with hydrogen and short organic acids. As the solubility of oxygen in water is low, and because oxygen is the preferred electron acceptor by many microbes utilising organic compounds in shallow groundwater, anaerobic reduced environments and processes usually dominate at depth in the subterranean environment.

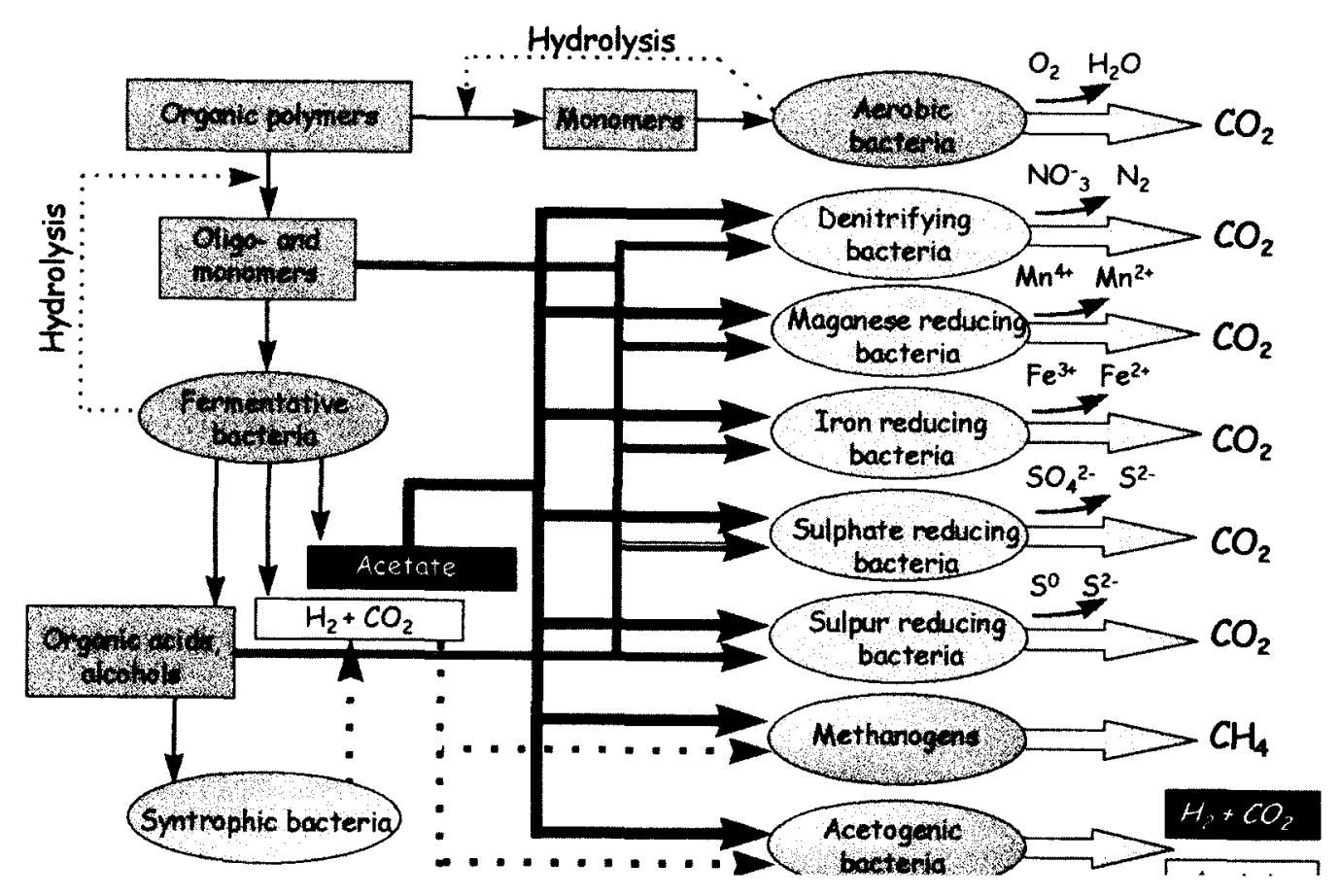

Figure 1 Possible pathways for the flow of carbon in the subterranean environment. Organic carbon is respired with oxygen, if present, or else fermentation and anaerobic respiration with an array of different electron acceptors occur. 


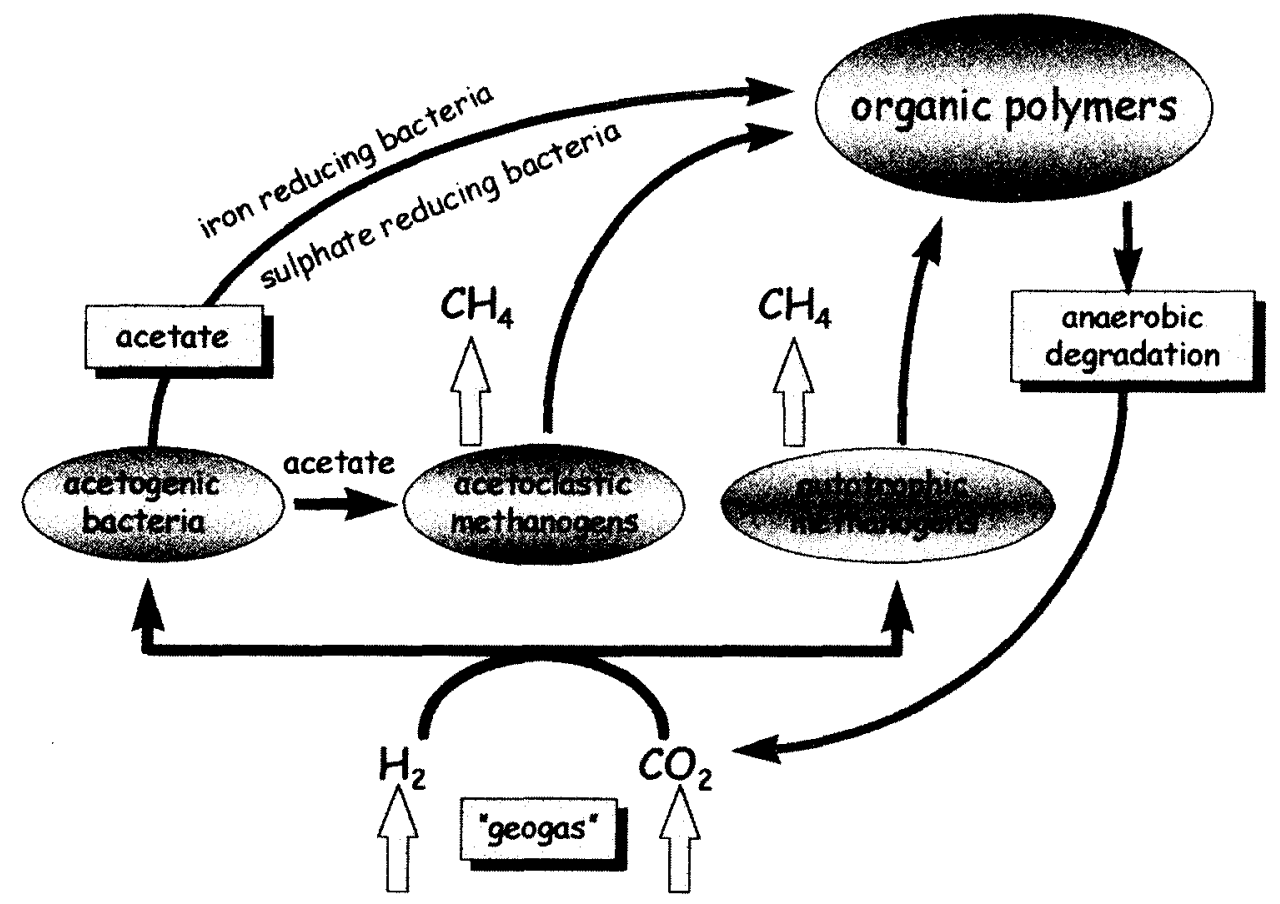

Figure 2 The deep hydrogen driven biosphere hypothesis, illustrated by its carbon cycle. At relevant temperature $\left(0-110^{\circ} \mathrm{C}\right)$ and water availability conditions, subterranean microorganisms are capable of performing a life cycle that is independent of sun-driven ecosystems. Hydrogen and carbon dioxide from deep within the earth's crust or from sedimentary deposits of organic carbon can be used as energy and carbon sources. Phosphorus is available in minerals like apatite and nitrogen for proteins, nucleic acids etc. can be obtained via nitrogen fixation; this gas is predominant in most ground waters.

\section{Hydrogen-dependent microbes}

The Swedish research program on subterranean microbiology (Pedersen, 1993b, 1996; Pedersen and Karlsson, 1995) has been performed at two sites, the Stripa research mine in the middle of Sweden (Ekendahl and Pedersen, 1994, Ekendahl et al., 1994, Pedersen and Ekendahl, 1992a) and the area. The Äspö investigation area, situated on the south eastern coast of Sweden, is a part of the Precambrian bedrock where the Småland granites predominate over the older, Sveocokarelian complexes. This is where the Äspö hard rock laboratory (HRL) is situated, at $460 \mathrm{~m}$ below the surface of the island $\ddot{A}$ spö and microbial investigations have been performed there from 1986 to present (Banwart et al., 1996, Pedersen and Ekendahl, 1990, 1992b, Pedersen et al., 1996).

Throughout the above mentioned work. numerous results have indicated the presence of autotrophic microorganisms in the deep environments that utilise hydrogen as a source of energy for growth with carbon dioxide as the carbon source (Pedersen and Ekendahl, 1990). We have suggested the possibility of a hydrogen-driven biosphere in deep granite earlier (Pedersen and Albinsson, 1992; Pedersen, 1993b), but solid evidence was lacking. Figure 2 schematically depicts possible routes of carbon and energy in such a biosphere. Acetogenic bacteria have the capability of reacting hydrogen with carbon dioxide to acetate, thereby producing energy (ATP) and reducing power for metabolism. Methanogens produce methane from hydrogen and carbon dioxide (autotrophic methanogens) or from acetate (acetoclastic methanogens). Our present research tasks are aiming at collecting evidence for this model, and concentrate on acetogenic bacteria and methanogens. Presence and activity of iron and sulphate reducing bacteria in the Äspö rock aquifers have been well documented earlier (Banwart et al., 1996; Laaksoharju et al.; 1995, Pedersen, 1996; Pedersen and Karlsson, 1995). Recent results obtained by us from the Äspö HRL tunnel demonstrate from 0.1 to $100 \mu \mathrm{M}$ of hydrogen and from 0.1 to $1.000 \mu \mathrm{M}$ of methane in ground water down to $440 \mathrm{~m}$ depth at Äspö HRL and that autotrophic methanogens, acetogenic bacteria and acetoclastic methanogens all are present and active in the investigated ground water (Kotelnikova and Pedersen, 1997).

Acetogenic bacteria have been isolated from the Äspö tunnel ground water (Pedersen et al., 1996) and experiments with an extra hydrogen addition to Äspö HRL ground water resulted in rapid acetate production. The acetate produced can be used by acetoclastic methanogens, iron and sulphate reducing bacteria and other heterotrophic microorganisms, thereby constituting a transformation route of inorganic carbon to organic carbon with hydrogen as the reductant (Figure 2 ). Our results on presence, diversity and activity of methanogens in 20 different boreholes at Äspö HRL (10-440 m depth) are presently in preparation for publication. Briefly, pure cultures of autotrophic, rod-shaped methanogens have been isolated and $16 \mathrm{~S}$ rRNA gene data indicates that they are related to the genus Methanobacterium. Viable cell counts (most probable numbers) varied from 10 to 430000 methane producing organisms $\mathrm{ml}^{-1}$. In situ conversion of ${ }^{14} \mathrm{C}$-carbon dioxide to ${ }^{14} \mathrm{C}$-methane has been detected repeatedly. The distribution, numbers and physiological diversity of three methanogens detected seem to be governed by the carbon dioxide concentration, salinity and organic carbon content.

\section{The deep hydrogen-driven biosphere}

Until recently, it has been a general concept that all life on earth depends on the sun via photosynthesis, including most of the geothermal life forms in deep sea trenches as they use oxygen for the oxidation of reduced inorganic compounds (almost all oxygen on earth is produced via photosynthesis). Here, it is suggested that a deep subterranean granitic biosphere exists, driven by the energy available in hydrogen formed through radiolysis, mineral reactions or by volcanic activity. Knowledge about this biosphere is just beginning to emerge and it will expand the spatial borders for life 
from a thin layer on the surface of the planet Earth and in the seas to a several kilometre thick biosphere reaching deep below the ground surface and the sea floor. If this theory holds, life may have been present and active deep down in Earth for a very long time, and it cannot be excluded that the place for the origin of life was a deep subterranean igneous rock environment (probably hot with a high pressure) rather than a surface environment. The closest species to the root of the phylogenetic $16 \mathrm{~S}$ rRNA tree, as known today, are obligate hydrogen-utilising thermophiles-supporting the idea of a deep hot origin of life. A rather spectacular conclusion is that life on other planets should probably not be searched for only on the surface but rather deep down in the subsurface.

\section{References}

Banwart, S., Tullborg, E. -L.,Pedersen, K., Gustafsson, E., Laaksoharju, M., Nilsson, A.-C., Wallin, B., and Wikberg, P., 1996, Organic carbon oxidation induced by largescale shallow water intrusion into a vertical fracture zone at the Âspö Hard Rock Laboratory (Sweden). Journal of Contaminant Hydrology, v. 21, p. 115-125.

Ekendahl, S., Arlinger, J., Stăhl, F., and Pedersen, K., 1994, Characterization of attached bacterial populations in deep granitic groundwater from the Stripa research mine with $16 \mathrm{~S}$-rRNA gene sequencing technique and scanning electron microscopy. Microbiology, v. 140, p. 15751583 .

Ekendahl, S., and Pedersen, K., 1994, Carbon transformations by attached bacterial populations in granitic ground water from deep crystalline bedrock of the Stripa research mine. Microbiology, v. 140, p. 1565-1573.

Fredrickson, J.K., and Onstott, T.C., 1996, Microbes deep inside the earth. Scientific American, v. 275, p.42-47.

Ghiorse, W.C., and Wilson, J.T., 1988, Microbial ecology of the terrestrial subsurface. Advances in Applied Microbiology, v.33, p. 107-172.

Kotelnikova, S., and Pedersen, K., 1997, Evidence for methanogenic Archaea and homoacetogenic Bacteria in deep granitic rock aquifers. FEMS Microbiology Reviews, v. in press,

Laaksoharju, M., Pedersen, K., Rhen, I., Skarman, C., Tullborg, E.-L., Wallin, B. and Wikberg,W. 1995. Sulphate reduction in the Äspö HRL tunnel. SKB Technical Report 95-25. Swedish Nuclear fuel and Waste Management Co., Stockholm, pp. 1-87.

Matthess, G., Frimmel, F.H., Hirsch, P., Schulz, H.D. and Usdowski, E. 1992. Progress in hydrogeochemistry. Springer-Verlag, pp. 1-544.

Pedersen. K., 1993a, The deep subterranean biosphere. Earth-Science Reviews, v. 34,p. 243-260.

Pedersen, K., 1993b, Bacterial processes in nuclear waste disposal. Microbiology Europe, v.1, p. 18-23.

Pedersen, K., 1996, Investigations of subterranean bacteria in deep crystalline bedrock and their importance for the disposal of nuclear waste. Canadian Journal of Microbiology, v. 42,p. 382-391.
Pedersen, K., and Albinsson, Y., 1992, Possible effects of bacteria on trace element migration in crystalline bed-rock. Rediochimica Acta, v.58/59,p. 365-369.

Pedersen, K., Arlinger, J., Ekendahl, S., and Hallbeck, L., 1996, 16S rRNA gene diversity of attached and unattached groundwater bacteria along the Access tunnel to the Äspö Hard Rock Laboratory, Sweden. FEMS Microbiology Ecology, v, 19,p. 249-262.

Pedersen, K., and Ekendahl, S., 1990, Distribution and activity of bacteria in deep granitic groundwaters of southeastern Sweden. Microbial Ecology. v. 200 , p. $37-52$.

Pedersen, K., and Ekendahl, S., 1992a, Incorporation of CO2 and introduced organic compounds by bacterial populations in groundwater from the deep crystalline bedrock of the Stripa mine. Journal of General Microbiology, v. 138,p. 369-376.

Pedersen, K., and Ekendahl, S., 1992b, Assimilation of $\mathrm{CO} 2$ and introduced organic compounds by bacterial communities in ground water from Southeastern Sweden deep crystalline bedrock. Microbial Ecology, v. 22,p. 1-14.

Pedersen, K. and Karlsson, F., 1995. Investigations of subterranean bacteriaTheir importance for performance assessment of radioactive waste disposal. SKB Technical Report 95-10. Swedish Nuclear Fuel and Waste Management Co., Stockholm, pp. 1-222.

Stevens, T.O., and Mckinley, J.P., 1995, Lithoautotrophic microbial ecosystem in deep basalt aquifers. Science, v. 270, p. 450-453.

Karsten Pedersen was born in Malmö, Sweden, on August 1, 1952. He received his $P h D$, in microbiology 1982 from the University of Goteborg, Sweden. He presently holds a position as Associate Professor at the Department of General and Marine Microbiology, University of Göteborg, Sweden where he has been a member of the research and teaching staff since 1982. He has published 31 papers in international journals and has written 21 reports for national research agencies. He is project leader for several research projects of which the most recognised is the study of the deep biosphere in granitic rock aquifers and elsewhere.

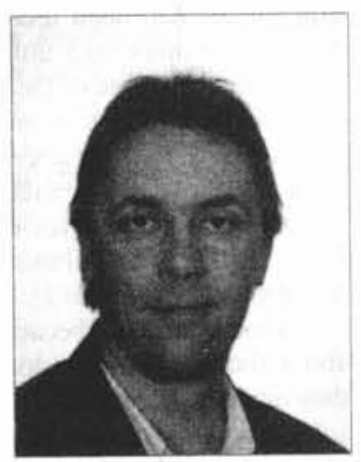

